\section{Relative Fitness of Glyphosate- resistant Creeping Bentgrass Lines in Kentucky Bluegrass}

\author{
D.S. Gardner ${ }^{1}$ and T.K. Danneberger \\ Department of Horticulture and Crop Science, 2021 Coffey Road, The Ohio \\ State University, Columbus, OH 43210-1086
}

\section{E. Nelson \\ The Scotts Company, 14111 Scottslawn Road, Marysville, OH 43041}

\author{
W. Meyer and K. Plumley \\ Department of Plant Biology and Pathology, Cook College, Rutgers, The State \\ University of New Jersey, New Brunswick, NJ 08901
}

Additional index words. Agrostis stolonifera, Poa pratensis, genetically modified organism

\begin{abstract}
Genetically transformed cultivars of creeping bentgrass (Agrostis stolonifera L. syn. Agrostis palustris Huds.) that are resistant to glyphosate have been developed by a collaboration of the Scotts and Monsanto companies. Prior to commercial release, we desired to determine if the transformed plants behave similarly to traditional creeping bentgrass except for the effects expected from the inserted gene, i.e., resistance to glyphosate. Therefore, studies were initiated on 23 June 2000 in Marysville, Ohio; 14 July 2000 in Middleton, N.J.; and 20 June 2000 in Gervais, Ore., to examine the relative lateral spread and competitive ability of several transformed lines of creeping bentgrass, non-transformed controls, and reference cultivars. Vegetative plugs of creeping bentgrass were transplanted into a mature stand of Kentucky bluegrass (Poa pratensis L.) or a uniform mixture of Kentucky bluegrass with perennial ryegrass (Lolium perenne $L$.). The plots were watered as needed to prevent moisture stress. Competitive ability of the transformed plants and reference cultivars were determined monthly by measuring the average diameter of the creeping bentgrass patch. On all observation dates, the transgenic lines, as a group, were smaller in average diameter $(5.1-7.6 \mathrm{~cm})$ compared to the reference cultivars $(5.4-14.2$ $\mathrm{cm})$ and non-transformed control lines $(5.9-10.2 \mathrm{~cm})$. At the end of the observation period (Aug. 2001), no differences $(\boldsymbol{P}=\mathbf{0 . 0 5})$ in lateral spread were observed between individual lines of transgenic bentgrass. Three lines of interest, ASR365, ASR368, and ASR333, had lateral spread rates that are similar to, or less than, that of their non-transformed parent and the conventional creeping bentgrass cultivars tested. Chemical names used: $N$-(phosphonomethyl) glycine (glyphosate).
\end{abstract}

Creeping bentgrass is a widely used turfgrass species on golf course greens, tees, and fairways in the northern United States. A disadvantage of using creeping bentgrass is its vulnerability to a wide range of pest problems. Annual bluegrass (Poа аппиа L.) is a serious weedy grass problem in creeping bentgrass putting greens (Turgeon, 2002). No herbicide chemistry is available to consistently effectively control annual bluegrass in creeping bentgrass.

Glyphosate (the active ingredient in Roundup ${ }^{\circledR}$ brand herbicides) is a broad-spectrum herbicide that is toxic to plants, fungi, and bacteria (Gresshoff, 1979). Glyphosate's mode of action is through inhibition of 5-enolpyruvylshikamate 3-phosphate (EPSP) synthase. EPSP

\footnotetext{
Received for publication 2 Apr. 2002. Accepted for publication 15 Oct. 2002. Salaries and research support provided in part by State and Federal funds appropriated to the Ohio Agricultural Research and Development Center, The Ohio State University. Journal Article Number HCS01-36.

${ }^{1}$ To whom reprint requests should be addressed; e-mail address: gardner.254@osu.edu
}

synthase catalyzes the formation of EPSP from shikimate 3- phosphate and phosphoenolpyruvate (PEP). Glyphosate inhibits this reaction by interfering with binding of PEP(Thompson et al., 1987). Glyphosate-resistant crops have been developed by genetically engineering plants with a gene that codes for an EPSP synthase protein with lower sensitivity to glyphosate (Thompson et al., 1987).

The Monsanto and Scotts companies have collaborated in the development of genetically engineered creeping bentgrass cultivars that are resistant to glyphosate via the heterologous expression of a gene from the CP4 strain of Agrobacterium sp. encoding for a glyphosate-resistant form of EPSP. The gene and construct are similar to those used to modify other glyphosate-resistant crops, such as soybean [Glycine max (L.) Merr.] (Padgett et al., 1995). Adoption of glyphosate-resistant creeping bentgrass could potentially simplify and improve the control of a wide array of invasive annual, biennial, and perennial grass, broadleaf, and sedge species that can invade golf turf. The availability of glyphosate as an over-the-top treatment on glyphosate-resistant creeping bentgrass could significantly reduce the need for many of these herbicides, resulting in several important environmental, health, and safety benefits (Padgette et al., 1995).

Glyphosate binds rapidly to the soil, making it resistant to leaching (Gustafson, 1989). It has low toxicity to mammals, birds, and fish and is one of the few commercially available herbicides classified as "Category E" by the EPA (evidence of non-carcinogenicity for humans).

Transgenic plant cultivars are regulated in the United States by the USDA, EPA, and FDA. These agencies assess the human and environmental safety of these new crop varieties, and their approval is required prior to commercial release. The USDA in particular performs an environmental risk assessment, which includes a determination of whether glyphosate-resistant cultivars are any more likely to become a weed than cultivars developed by traditional breeding techniques. Therefore, in contribution to this risk assessment, our study was designed to compare the relative lateral spread rates of several glyphosate-resistant lines to their respective non-transformed parents and to traditional creeping bentgrass cultivars when transplanted into a mature and competing turf stand. The results of this study will help clarify whether glyphosate-resistant creeping bentgrass cultivars have gained competitive ability greater than their non-transformed parents or current commercially available cultivars.

\section{Materials and Methods}

Bentgrass plant tissue that received DNA conferring tolerance to glyphosate was embryonic plant callus from single seeds of creeping bentgrass identified as B99054P, B99061R, and C99056L. Biolistic transformation was used to produce the glyphosate-resistant events (Lee, 1996). These cells were transferred to selective media containing glyphosate and only those cells transformed with the cp4 epsps gene continued to grow. This is a single insertion event and acts as a dominant trait. The events selected for this study were chosen from among these transformed plant cells.

For each reference cultivar, random seedlings from commercial seed lots were grown in pots and then cloned from stolon nodes grown in Jiffy ${ }^{\circledR}$ Pellets (42-mm diameter; Jiffy Products of America, Batavia, Ill.) in a cold frame in Gervais, Ore. (Table 1). All plants were cloned at the same time to maintain age equivalence. All other events and non-transformed controls were clones from stolon nodes. The plants were irrigated to prevent drought stress and fertilized to eliminate visible nutrient deficiencies. Plants were maintained at $1.25-\mathrm{cm}$ height of cut. Plants of similar age and size were selected for planting in established turf environments.

Field studies were initiated on 23 June 2000 in Marysville, Ohio; 14 July 2000 in New Brunswick, N.J.; and 20 June 2000 in Gervais, Ore. The turf at the New Jersey location was a stand of 'Baron' Kentucky bluegrass established in 1998. The turf at the Ohio location was a stand of 'Victa', 'Coventry', and 'Abbey' 
Table 1. Cultivars and lines of creeping bentgrass tested for aggressiveness in a stand of Kentucky bluegrass and/or perennial ryegrass at three locations.

\begin{tabular}{ccc}
\hline $\begin{array}{l}\text { Glyphosate-resistant lines: } \\
\text { ASR315 }\end{array}$ & ASR331 \\
ASR346 & ASR364 & ASR33 \\
ASR368 & ASR394 & ASR365 \\
ASR812 & ASR814 & ASR801 \\
Non-transformed control plants: & ASR815 \\
C99056L (corresponds to all lines except ASR 365, 368, and 394) \\
B99061R (corresponds to ASR 368 and ASR 365) \\
B99054P (corresponds to ASR 394) \\
Reference cultivars: \\
Penncross & \\
Crenshaw & \\
Penn A-4 & \\
\hline
\end{tabular}

Kentucky bluegrass established in 1996. The turf at the Oregon location was a uniform stand of 'Victa' and 'Abbey' Kentucky bluegrass and 'Divine' and 'Majesty' perennial ryegrass ( $\mathrm{Lo}$ lium perenne $\mathrm{L}$.) that was established in 1998. The turf plots at each location were maintained under a medium-high maintenance regime and were in good condition.

Soil cores $(35 \mathrm{~mm}$ in diameter and $60 \mathrm{~mm}$ deep) were removed from the original turf area on $60-90 \mathrm{~cm}$ centers with an auger bit. Bentgrass plugs were transplanted directly into the core holes so that the plant crowns were at or slightly below the soil surface and with firm contact between the Jiffy pot media was and the field soil. The plots were irrigated as needed to prevent stress during a 6-week establishment phase, and then irrigated to maintain the existing turf.

Plots were mown regularly at a clipping height of $1.25 \mathrm{~cm}$ in Oregon, $3.75 \mathrm{~cm}$ in New Jersey, and $5 \mathrm{~cm}$ in Ohio. Nitrogen (24-36 $\mathrm{Kg} \cdot \mathrm{ha}^{-1}$ per month during active growth ap- plied as urea), potassium, and phosphorus were applied as needed to compensate for visual deficiency symptoms. Pulverized lime (1029 $\mathrm{Kg} \cdot \mathrm{ha}^{-1}$ ) was applied at the New Jersey location in June 2001 to adjust the soil pH. Bensulide (O,O-diisopropyl $\mathrm{S}$-2-phenylsulfonylaminoethyl phosphorodithioate) was applied in Aug. 2000, and dithiopyr (S,S'-dimethyl 2-difluoromethyl-4-isobutyl-6-trifluoromethylpyridine-3,5-dicarbothioate) was applied to the plots in New Jersey in May 2001 for control of weeds. In Oregon, Dicamba $(3,6-$ dichloro- $O$-anisic acid) was applied to the plots in Mar. 2001. All pesticides were applied at label rates. However, no pesticides were applied to the plots at the Ohio location.

Bentgrass plant diameter was measured in centimeters during the first week of each month of the growing season. Mean plant diameter was calculated as an average of two perpendicular measurements made on each tiller plot. Field monitoring data was collected monthly noting the presence and intensity or absence of disease [dollar spot (Sclerotinia homeocarpa F.T. Bennett), brown patch (Rhizoctonia solani Kuhn), take-all patch (Gaeumannomyces graminis (Sacc.) Arx \& Olivier var. avenae Turnur), Pythium, etc.], beneficial or pest insects [White grubs, cutworms (Agrotis ipsilon Hufnagel), etc.] or other vertebrates and invertebrates (earthworms, etc.). The duration of the study was based on previously published reports concerning bentgrass population dynamics (Cattani et al., 1991; Jonsdottir, 1991).

The study was conducted as a completely randomized design with three replicates at each of three locations. Analysis of variance with all locations combined revealed significant location effects (SAS Institute, 1990). Therefore, the data were analyzed separately for each location. Means were compared using Fisher's protected LSD, which was chosen because it has the highest power of the pair-wise separation procedures and individual comparisons were of more interest than experiment-wise comparisons in this study (Carmer and Walker, 1985; Chew, 1976).

\section{Results and Discussion}

Lateral spread of all the creeping bentgrass cultivars and lines was significantly $(P=0.05)$ greater in Oregon as compared to New Jersey and Ohio (analysis not shown). Increased lateral spread recorded in Oregon may have been due to more favorable growing conditions in Oregon. Additionally, in Oregon the height of cut was $1.25 \mathrm{~cm}$ and bentgrass is more tolerant of low clipping heights than either the Kentucky bluegrass and perennial ryegrass turf (Beard, 1973; Turgeon, 2002). In both New Jersey and Ohio, the higher height of cut may have favored the bluegrass over creeping bentgrass entries. Other factors may also have contributed to the

Table 2. Mean diameter $(\mathrm{cm})$ of creeping bentgrass plugs of reference, non-transformed controls, and transformed glyphosate resistant lines from Aug. 2000 to July 2001 at New Brunswick, N.J.

\begin{tabular}{|c|c|c|c|c|c|c|c|c|c|c|c|c|}
\hline \multirow{3}{*}{$\begin{array}{l}\text { Cultivar or } \\
\text { line }\end{array}$} & \multicolumn{6}{|c|}{2000} & \multicolumn{6}{|c|}{2001} \\
\hline & \multicolumn{2}{|c|}{ August } & \multicolumn{2}{|c|}{ September } & \multicolumn{2}{|c|}{ October } & \multicolumn{2}{|c|}{ May } & \multicolumn{2}{|c|}{ June } & \multicolumn{2}{|c|}{ July } \\
\hline & Mean & $\mathrm{SD}^{\mathrm{Z}}$ & Mean & $\mathrm{SD}$ & Mean & $\mathrm{SD}$ & Mean & $\mathrm{SD}$ & Mean & SD & Mean & SD \\
\hline & & & & & & $-\mathrm{cm}-$ & & & & & & ---- \\
\hline Penn A-4 & 6.5 & 2.6 & 6.6 & 3.4 & 7.8 & 5.7 & 4.2 & 3.8 & 8.5 & 7.1 & 10.2 & 7.4 \\
\hline Crenshaw & 6.3 & 1.8 & 7.3 & 3.1 & 12.8 & 3.9 & 14.7 & 7.7 & 19.0 & 8.4 & 18.6 & 5.8 \\
\hline Penncross & 7.6 & 2.7 & 8.3 & 3.4 & 12.2 & 3.4 & 14.2 & 7.5 & 18.6 & 4.5 & 21.2 & 4.0 \\
\hline C99056L & 6.8 & 2.8 & 7.3 & 1.6 & 8.0 & 3.1 & 8.3 & 7.2 & 7.8 & 7.5 & 10.5 & 9.1 \\
\hline ASR315 & 0.8 & 0.8 & 1.7 & 1.5 & 1.0 & 1.0 & 0.3 & 0.6 & 0.7 & 1.2 & 0.7 & 1.2 \\
\hline ASR331 & 1.5 & 0.5 & 1.7 & 1.5 & 1.0 & 1.0 & $\mathrm{ND}^{\mathrm{y}}$ & --- & ND & -- & ND & -- \\
\hline ASR333 & 4.3 & 0.8 & 4.3 & 1.5 & 8.8 & 1.9 & 2.7 & 2.5 & 2.3 & 2.5 & 3.3 & 3.1 \\
\hline ASR346 & 1.8 & 1.3 & 2.3 & 1.2 & 3.2 & 1.3 & ND & --- & ND & --- & ND & --- \\
\hline ASR364 & 2.3 & 1.2 & 1.5 & 1.3 & 1.3 & 2.3 & ND & --- & ND & --- & ND & --- \\
\hline ASR801 & 4.3 & 1.0 & 2.5 & 1.5 & 2.0 & 1.0 & ND & --- & ND & --- & ND & --- \\
\hline ASR812 & 1.8 & 1.9 & 1.7 & 2.1 & 1.3 & 2.3 & 0.7 & 1.2 & ND & --- & ND & --- \\
\hline ASR814 & 3.2 & 2.9 & 5.0 & 1.8 & 4.0 & 3.3 & ND & -- & ND & --- & ND & --- \\
\hline ASR815 & 1.3 & 1.2 & 1.3 & 1.5 & 1.3 & 1.2 & 0.7 & 1.2 & 1.0 & 1.0 & 1.3 & 2.3 \\
\hline B99061R & 4.7 & 2.6 & 4.0 & 1.8 & 6.5 & 3.5 & ND & 0.0 & 7.0 & 7.5 & 5.2 & 5.3 \\
\hline ASR365 & 5.0 & 1.3 & 4.3 & 0.3 & 4.2 & 3.6 & 2.7 & 2.3 & 5.7 & 5.5 & 5.3 & 4.6 \\
\hline ASR368 & 7.8 & 0.6 & 8.8 & 1.3 & 11.3 & 2.5 & 10.5 & 5.1 & 12.5 & 0.5 & 13.8 & 3.5 \\
\hline B99054P & 4.5 & 4.1 & 3.7 & 3.2 & 6.2 & 5.4 & 4.2 & 4.0 & 8.3 & 7.2 & 11.3 & 10.0 \\
\hline ASR394 & 6.7 & 2.0 & 7.2 & 0.3 & 12.0 & 1.5 & 9.8 & 0.8 & 11.8 & 0.8 & 17.5 & 3.3 \\
\hline $\operatorname{LSD}_{(0.05)}$ & 3.3 & & 3.9 & & 5.5 & & 7.4 & & 8.3 & & 7.8 & \\
\hline
\end{tabular}

$\mathrm{z}_{\mathrm{SD}}=$ Standard deviation of the mean diameter of the cultivar or line.

${ }^{\mathrm{y}} \mathrm{ND}=$ Plant was not accessible during a particular observation period either due to plant death, or to temporary dormancy. In cases of dormancy, a plant measurement $>0.0$ may appear in subsequent months. 
differences between locations, including soil type and cultivars or species composition in the test plots. Because of the significant location effects, the data were analyzed separately by location.

At all locations, no differences between the reference, non-transformed or transformed lines, were observed when monitoring disease incidence, insect susceptibility, presence or absence of beneficial organisms, plant growth characteristics, or aggressiveness characteristics on any date (data not shown). Several of the lines tested in this study are no longer being considered for commercial release. The lines of primary interest in this study were ASR 333, ASR 365, and ASR 368.

New Jersey. At New Brunswick, N.J., several transformation events did not survive after May 2000 (Table 2), indicating that they lacked competitive ability necessary to persist in a stand of Kentucky bluegrass. However, the mean diameter of one of the lines of interest, ASR 368, was greater than its corresponding non-transformed parent (B99061R) during Sept. 2000, May 2001, and July 2001 (Table 2). The diameter of ASR 368 was statistically similar to each of the reference cultivars for every rating over two growing seasons during the study period.ASR 368 was also statistically equivalent to non-transformed parent plant B99054P during every month during two seasons of growth except Sept. 2000.

Two other lines of interest, ASR 333 and ASR 365, were significantly smaller than 'Penncross' and 'Crenshaw', but similar in plant diameter to their non-transformed parents, C99056Land B99061R, respectively, and 'Penn A-4' (Table 2). Diameters of ASR 333 were also smaller than those of 'Penncross' during Sept. 2000, and were smaller than
'Penncross' and 'Crenshaw' from May through July 2001. Throughout the study period, the diameter of ASR 365 was equivalent to its non-transformed parent control, but smaller than 'Penncross'.

Oregon. At the Oregon location, several of the transformation events were smaller in mean diameter than their corresponding nontransformed parent throughout the study period (Table 3). However, the mean diameter of ASR 368 was larger than that of its non-transformed parent (B99061R) during Aug., Nov., and Dec. 2000, but was equivalent during September (Table 3). ASR 368 was not different from any of the reference cultivars during Sept. through Dec. 2000 and was statistically equivalent to 'Penncross' in August. No differences were observed in the lateral spread of ASR 333 or ASR 365 compared to their non-transformed parents (C99056Land B99061R, respectively)

Table 3. Mean diameter $(\mathrm{cm})$ of creeping bentgrass plugs of reference, non-transformed controls, and transformed glyphosate-resistant lines from Aug. 2000 to Aug. 2001 at Gervais, Ore.

\begin{tabular}{|c|c|c|c|c|c|c|c|c|c|c|c|c|c|c|c|c|}
\hline \multirow{3}{*}{$\begin{array}{l}\text { Cultivar or } \\
\text { line }\end{array}$} & \multicolumn{8}{|c|}{2000} & & & & & & & & \\
\hline & \multicolumn{2}{|c|}{ August } & \multicolumn{2}{|c|}{ September } & \multicolumn{2}{|c|}{ November } & \multicolumn{2}{|c|}{ December } & & & & & & & & \\
\hline & Mean & $\mathrm{SD}^{\mathrm{Z}}$ & Mean & $\mathrm{SD}$ & Mean & $\mathrm{SD}$ & Mean & SD & & & & & & & & \\
\hline & & & & & & & & & & & & & & & & \\
\hline Penn A-4 & 6.6 & 1.6 & 4.6 & 1.4 & 5.1 & 1.4 & 5.6 & 1.7 & & & & & & & & \\
\hline Crenshaw & 6.7 & 1.5 & 4.9 & 1.0 & 6.8 & 1.0 & 6.7 & 1.1 & & & & & & & & \\
\hline Penncross & 7.3 & 0.9 & 5.5 & 0.7 & 5.6 & 1.7 & 6.2 & 0.9 & & & & & & & & \\
\hline C99056L & 5.9 & 1.6 & 5.8 & 1.3 & 3.8 & 2.8 & 6.8 & 3.4 & & & & & & & & \\
\hline ASR315 & 4.8 & 0.6 & 4.0 & 0.5 & 3.5 & 1.3 & 4.2 & 0.6 & & & & & & & & \\
\hline ASR331 & 4.1 & 1.3 & 3.2 & 0.3 & 3.2 & 1.3 & 4.0 & 1.8 & & & & & & & & \\
\hline ASR333 & 7.7 & 2.0 & 4.8 & 1.2 & 4.5 & 1.7 & 6.2 & 1.0 & & & & & & & & \\
\hline ASR346 & 6.3 & 1.2 & 3.8 & 0.8 & 4.3 & 0.8 & 4.3 & 0.6 & & & & & & & & \\
\hline ASR364 & 3.8 & 0.8 & 3.0 & 0.5 & 2.8 & 0.3 & 3.3 & 0.8 & & & & & & & & \\
\hline ASR801 & 6.3 & 0.6 & 4.7 & 0.8 & 4.3 & 0.3 & 4.3 & 0.6 & & & & & & & & \\
\hline ASR812 & 6.1 & 1.7 & 3.8 & 0.8 & 4.2 & 1.8 & 3.5 & 0.9 & & & & & & & & \\
\hline ASR814 & 6.9 & 1.7 & 3.8 & 0.8 & 4.7 & 1.3 & 5.0 & 1.7 & & & & & & & & \\
\hline ASR815 & 4.2 & 0.5 & 3.5 & 0.9 & 2.7 & 0.3 & 3.0 & 0.5 & & & & & & & & \\
\hline B99061R & 6.2 & 2.9 & 4.0 & 0.5 & 4.3 & 1.4 & 4.0 & 0.0 & & & & & & & & \\
\hline ASR365 & 7.1 & 1.8 & 3.8 & 1.4 & 5.5 & 1.7 & 5.0 & 1.0 & & & & & & & & \\
\hline ASR368 & 9.0 & 1.3 & 5.3 & 0.6 & 6.7 & 1.3 & 6.0 & 0.9 & & & & & & & & \\
\hline B99054P & 4.8 & 0.9 & 4.0 & 1.3 & 3.5 & 1.3 & 4.2 & 2.0 & & & & & & & & \\
\hline ASR394 & 6.4 & 1.2 & 5.3 & 0.3 & 6.5 & 1.3 & 6.0 & 0.5 & & & & & & & & \\
\hline \multirow[t]{2}{*}{$\operatorname{LSD}_{(0.05)}$} & 2.2 & & 1.5 & & 2.2 & & 2.0 & & & & & & & & & \\
\hline & \multicolumn{16}{|c|}{2001} \\
\hline \multirow{2}{*}{$\begin{array}{l}\text { Cultivar or } \\
\text { line }\end{array}$} & \multicolumn{2}{|c|}{ January } & \multicolumn{2}{|c|}{ February } & \multicolumn{2}{|c|}{ March } & \multicolumn{2}{|c|}{ April } & \multicolumn{2}{|c|}{ May } & \multicolumn{2}{|c|}{ June } & \multicolumn{2}{|c|}{ July } & \multicolumn{2}{|c|}{ August } \\
\hline & Mean & SD & Mean & SD & Mean & $\overline{\mathrm{SD}}$ & Mean & $\mathrm{SD}$ & Mean & $\overline{\mathrm{SD}}$ & Mean & $\overline{\mathrm{SD}}$ & Mean & $\overline{\mathrm{SD}}$ & Mean & $\mathrm{SD}$ \\
\hline Penn A-4 & 9.6 & 2.4 & 8.8 & 2.4 & 9.7 & 1.3 & 11.6 & 2.0 & 9.9 & 3.4 & 11.9 & 3.4 & 12.2 & 2.9 & 14.1 & 5.7 \\
\hline Crenshaw & 10.6 & 1.8 & 9.5 & 2.1 & 11.6 & 3.2 & 15.0 & 6.3 & 14.6 & 2.0 & 17.6 & 3.7 & 17.1 & 4.0 & 17.8 & 5.6 \\
\hline Penncross & 10.2 & 1.8 & 11.2 & 1.8 & 11.6 & 1.8 & 16.6 & 2.6 & 17.6 & 5.7 & 16.1 & 3.8 & 15.3 & 3.0 & 19.6 & 5.6 \\
\hline C99056L & 12.0 & 4.0 & 13.8 & 4.3 & 13.7 & 4.5 & 15.5 & 5.1 & 14.0 & 8.2 & 20.3 & 1.2 & 16.5 & 1.0 & 19.5 & 2.6 \\
\hline ASR315 & 6.7 & 1.0 & 6.2 & 0.8 & 6.2 & 0.8 & 6.2 & 0.6 & 5.3 & 1.3 & 4.2 & 0.8 & 3.5 & 2.6 & 2.7 & 2.9 \\
\hline ASR331 & 4.2 & 0.6 & 5.7 & 0.8 & 6.5 & 1.0 & 6.2 & 1.8 & 2.2 & 1.9 & 2.2 & 1.9 & 1.0 & 1.7 & 1.0 & 1.7 \\
\hline ASR333 & 12.2 & 3.8 & 10.8 & 0.8 & 12.2 & 3.8 & 12.2 & 5.5 & 12.7 & 3.3 & 9.3 & 4.5 & 10.0 & 2.8 & 10.2 & 4.6 \\
\hline ASR346 & 7.5 & 1.8 & 8.7 & 0.6 & 7.3 & 0.8 & 8.3 & 1.0 & 9.0 & 1.5 & 8.3 & 1.2 & 8.7 & 0.6 & 9.7 & 2.3 \\
\hline ASR364 & 5.2 & 0.8 & 5.3 & 0.6 & 5.7 & 1.0 & 5.5 & 1.3 & 11.7 & 5.9 & 5.2 & 2.0 & 5.8 & 0.8 & 4.2 & 3.6 \\
\hline ASR801 & 7.8 & 1.8 & 7.3 & 0.3 & 7.2 & 1.3 & 8.7 & 2.5 & 4.5 & 4.5 & 8.5 & 0.5 & 8.0 & 1.0 & 6.5 & 3.9 \\
\hline ASR812 & 6.0 & 0.5 & 5.3 & 2.0 & 6.0 & 0.5 & 7.3 & 1.1 & 7.0 & 4.8 & 8.8 & 4.5 & 7.8 & 5.0 & 7.0 & 4.4 \\
\hline ASR814 & 8.0 & 3.5 & 10.0 & 3.5 & 9.0 & 1.0 & 8.3 & 0.8 & 3.7 & 2.4 & 4.5 & 2.2 & 4.7 & 4.2 & 4.8 & 1.6 \\
\hline ASR815 & 4.7 & 0.3 & 5.0 & 1.0 & 4.8 & 1.3 & 5.0 & 2.0 & 5.0 & 4.3 & 4.3 & 2.0 & 3.7 & 3.2 & 2.2 & 1.9 \\
\hline B99061R & 7.0 & 0.9 & 7.7 & 1.2 & 6.7 & 1.6 & 9.0 & 3.8 & 8.5 & 1.7 & 10.0 & 1.8 & 10.7 & 1.6 & 12.0 & 3.9 \\
\hline ASR365 & 9.3 & 3.3 & 8.3 & 3.6 & 8.5 & 2.2 & 9.3 & 3.0 & 9.3 & 5.2 & 10.2 & 2.9 & 10.8 & 3.2 & 5.7 & 4.2 \\
\hline ASR368 & 13.7 & 2.8 & 13.5 & 2.0 & 13.5 & 2.5 & 14.3 & 0.8 & 13.2 & 1.4 & 15.7 & 3.3 & 14.5 & 0.9 & 18.2 & 5.3 \\
\hline B99054P & 8.0 & 3.6 & 7.0 & 2.2 & 9.0 & 4.5 & 8.2 & 7.1 & 10.3 & 8.5 & 9.2 & 7.1 & 8.8 & 7.0 & 10.5 & 7.5 \\
\hline ASR394 & 11.3 & 1.6 & 10.5 & 1.0 & 10.2 & 1.0 & 11.8 & 1.6 & 10.7 & 0.3 & 16.0 & 2.6 & 13.3 & 3.5 & 14.2 & 4.5 \\
\hline $\operatorname{LSD}_{(0.05)}$ & 3.4 & & 3.2 & & 3.5 & & 5.6 & & 6.5 & & 5.2 & & 5.0 & & 7.4 & \\
\hline
\end{tabular}

$\mathrm{z}_{\mathrm{SD}}=$ Standard deviation of the mean diameter of the cultivar or line. 
Table 4. Mean diameter (cm) of creeping bentgrass plugs of reference cultivars, non-transformed controls, and transformed glyphosate resistant lines from July 2000 to Aug. 2001 at Marysville, Ohio.

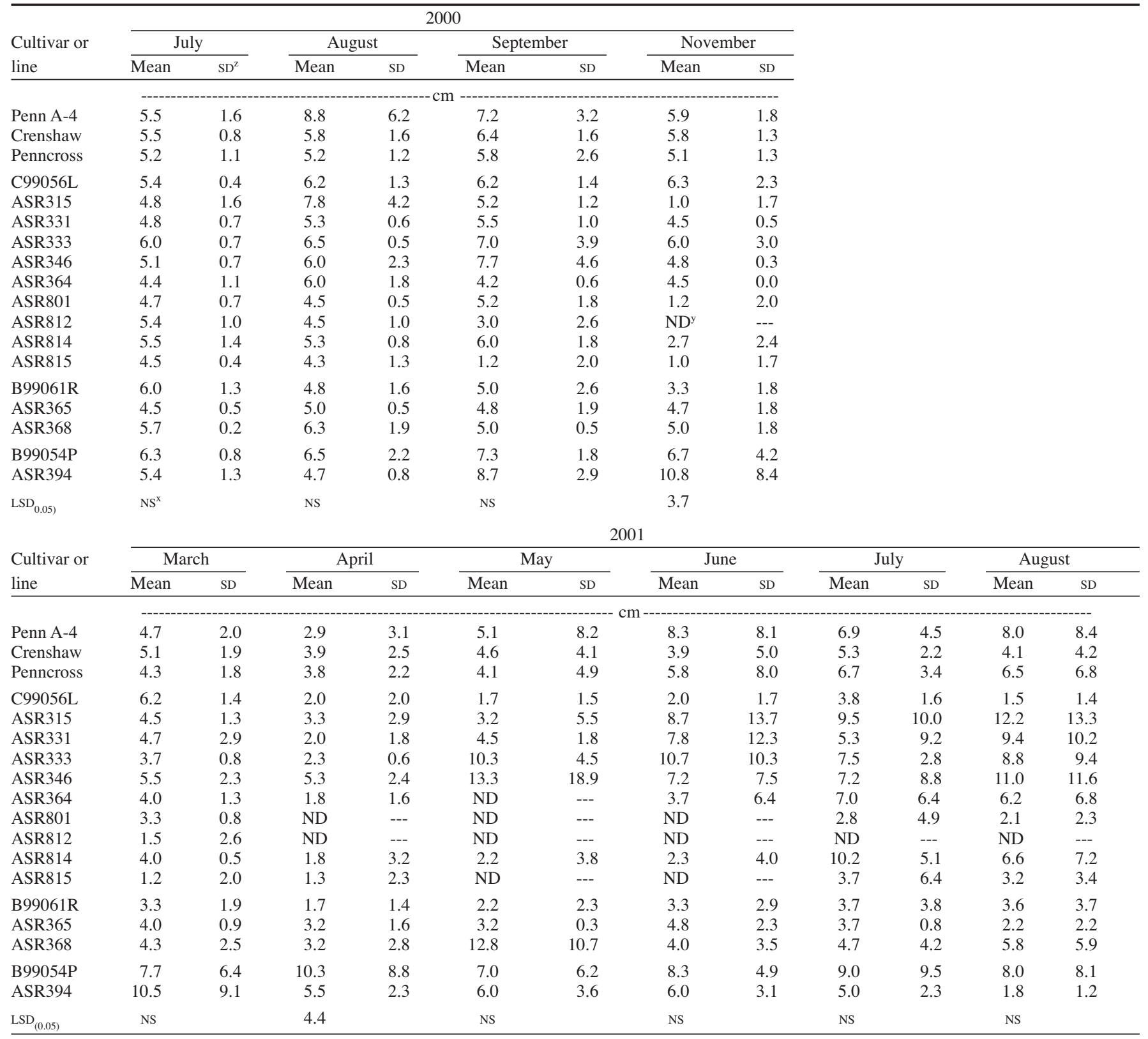

$\mathrm{z}_{\mathrm{SD}}=$ Standard deviation of the mean diameter of the cultivar or line.

${ }^{\mathrm{y}} \mathrm{ND}=$ plant was not accessible during a particular observation period either due to plant death, or to temporary dormancy. In cases of dormancy, a plant measurement $>0.0$ may appear in subsequent months.

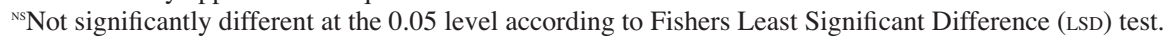

or plants from at least one of the reference cultivars during Sept. to Dec. 2000.

The lateral spread of ASR 365 was equivalent to all reference cultivars during January through March, but was significantly less than both 'Crenshaw' and 'Penncross' during Apr. 2001. Lateral spread of ASR 365 was statistically equivalent to that of its non-transformed parent control from Jan. through Apr. 2000. Lateral spread of ASR 365 was statistically similar to B99061R for each rating from May through August and was statistically equivalent to at least one of the reference cultivars from May to July. However, ASR 365 was significantly smaller than the reference cultivars during August.
The lateral spread of ASR 333 was equivalent to its non-transformed parent, C99056L, and reference cultivar, 'Penn A-4', from January to April. Plant diameter of ASR 333 was statistically similar to 'Penn A-4' from May to August, but was smaller than that of C99056L, 'Crenshaw', and 'Penncross' during June, July, and August (Table 3).

In contrast, the mean diameter of ASR 368 was significantly larger than its corresponding non-transformed parent, B99061R, from January to March and also June 2001, but was statistically equal to it in Apr., May, July, and Aug. 2001. However, throughout January to April, mean diameter of ASR 368 was statistically equivalent to mean diameter of plants from at least one of the reference cultivars and the non transformed plant C99056L. By July and August, ASR 368 was within the lateral spread range of 'Penn A-4', 'Crenshaw', and 'Penncross' (Table 3). No novel traits were exhibited by ASR 368 in Oregon that one could consider as adding any ecological advantage or disadvantage over conventional creeping bentgrasses.

Ohio. No-statistically significant differences in lateral spread were observed for any date at the Marysville, Ohio, location except in Nov. 2000 and April 2001 (Table 4). The density of the Kentucky bluegrass stand as well as some competition from broadleaf weeds, such as dandelion (Taraxicum officinale G.H. 
Weber ex Wiggers) and white clover(Trifolium repens $\mathrm{L}$.), resulted in more variation among replications of the same cultivar or line than were observed between cultivars and lines.

\section{Conclusions}

Most transgenic creeping bentgrass lines that are resistant to glyphosate displayed no additional increase in vegetative spread or relative fitness compared to traditional nontransgenic creeping bentgrass when competing with other species such as Kentucky bluegrass and perennial ryegrass maintained as turfgrass. One line, ASR 368, was occasionally more competitive than its non-transformed parent at the New Jersey and Oregon locations, but not at the Ohio location. However, on most dates, it was not more competitive than the commercial cultivars tested. The results from three diverse environments indicate that the heterologous expression of the Agrobacterium cp4 epsps enzyme, conferred no competitive advantage compared to non-transgenic creeping bentgrasses. These results indicate that the rate of lateral spread of ASR 368 in turf falls within the range of commercially available cultivars, and appears similar to its non-transformed par- ent control at the end of the study period. The other lines evaluated appear to have no more fitness or competitive advantage in turf situations than existing non-transformed control lines and commercial cultivars of creeping bentgrass under growing conditions in New Jersey, Ohio, or Oregon. Therefore, these transgenic lines would not be expected to have a competitive advantage in vegetative growth over non-transformed creeping bentgrass in either managed or unmanaged ecosystems. The variability in creeping bentgrass lateral spread observed in this study is less than that typically observed due to differences in climate and cultural practices, such as mowing, irrigation, and fertilization (Beard, 1973; Holt and Payne, 1951; Turgeon, 2002).

\section{Literature Cited}

Beard, J. 1973. Turfgrass Science and Culture, p. 386 Prentice Hall, Englewood Cliffs, N,J.

Carmer, S.G. and W.M. Walker. 1985. Pairwise multiple comparisons of treatment means in agronomic research. J. Agron. Ed. 14:19-26.

Cattani, D.J., M.H. Entz, and K.C. Bamford. 1991. Tiller production and dry matter accumulation in six creeping bentgrass genotypes grown in Manitoba. Can. J. Plant Sci. 71:595-599.
Chew, V. 1976. Comparing treatment means: A compendium. HortScience 11:348-357.

Gresshoff, P.M. 1979. Growth inhibition of glyphosate and reversal of its action by phenylalanine and tyrosine. Aust. J. Plant Physiol. 6:177-185.

Gustafson, D.I. 1989. Groundwater ubiquity score: A simple method for assessing pesticide leachability. Environ. Toxicol. Chem. 8:339-357.

Holt, E.C. and K.T. Payne. 1951. Variation in spreading rate and growth characteristics of creeping bentgrass seedlings. Agronomy J. 43:88-90.

Jonsdottir, G.A. 1991. Tiller demography in seashore populations of Agrostis stolonifera, Festuca rubra, and Poa irrigata. J. Vegetation Sci. 2:89-94.

Lee, L. 1996. Turfgrass biotechnology. Plant Sci. 115:1-8.

Padgette, S.R., K.H. Kolacz, X. Delannay, D.B. Re, B.J. LaVallee, C.N. Tinius, W.K. Rhodes, Y.I. Otero, G.F. Barry, D.A. Eichholtz, V.M. Peschke, D.L. Nida, N.B. Taylor, and G.M. Kishore. 1995. Development, identification, and characterization of a glyphosate-tolerant soybean line. Crop Sci. 35:1451-1461.

SAS Institute. 1990. SAS/STAT user's guide. Vol. 2, $4^{\text {th }}$ ed. SAS Inst., Cary, N.C

Thompson, G.A., W.R. Hiatt, D. Facciotti, D.M. Stalker, and L. Comai. 1987. Expression in plants of a bacterial gene coding for glyphosate resistance. Weed Sci. 35:19-23.

Turgeon, A.J. 2002. Turfgrass management. $6^{\text {th }}$ ed. Prentice Hall, Englewood Cliffs, N.J. 